\title{
INTEGRITAS PENDIDIKAN MULTIKULTURAL DALAM IMPLEMENTASI KURIKULUM 2013
}

\author{
M. Saipul Watoni \\ STIT Palapa Nusantara \\ msaipulwatoni@stitpn.ac.id
}

\begin{abstract}
Multicultural-based education is a tiered educational process that is able to become a binder and a bridge that accommodates differences in social, ethnic, gender and religious status in multicultural societies in order to create intelligent, wise and polite personalities in dealing with diversity problems. The multicultural education paradigm is very useful for building social harmony among the diversity of ethnicity, race, religion, culture and needs among us. Considering the complexity of plurality and multiculturalism in Indonesia in terms of socio-cultural and geographical conditions that are so diverse and broad, special strategies are needed to solve these problems through various fields; social, economic, cultural and educational. In this regard, multicultural-based education has actually been integrated in the 2013 curriculum. This is reflected in being integrated in the education curriculum and learning process.
\end{abstract}

Keywords: Multicultural Education

\begin{abstract}
Abstrak : Pendidikan berbasis Multikultural merupakan suatu proses pendidikan berjenjang yang mampu menjadi pengikat dan jembatan yang mengakomodasi perbedaan-perbedaan seperti status sosial,etnis, gender dan agama dalam masyarakat yang multikultural agar tercipta kepribadian yang cerdas, bijak dan santun dalam menghadapi masalah-masalah keberagaman. Paradigma pendidikan multikultural sangat bermanfaat untuk membangun harmoni sosial di antara keragaman etnik, ras, agama, budaya dan kebutuhan di antara kita. Mengingat kompleksitas pluralitas dan multikultural di Indonesia dilihat dari kondisi sosio-kultural maupun geografis yang begitu beragam dan luas, maka diperlukan strategi khusus untuk memecahkan persoalan tersebut melalui berbagai bidang; sosial, ekonomi, budaya, dan pendidikan. Berkaitan dengan hal ini, maka pendidikan berbasis multikultural sebenarnya telah terintegrasi dalam kurikulum 2013. Hal ini tercermin telah terintegrasi dalam kurikulum pendidikan dan proses pembelajaran.
\end{abstract}

Kata Kunci : Pendidikan Multikultural 


\section{PENDAHULUAN}

Indonesia adalah salah satu negara multikultur terbesar di dunia. Kenyataan ini dapat dilihat dari kondisi sosio kultural maupun geografis yang begitu beragam dan luas. Keragaman ini diakui atau tidak akan dapat menimbulkan berbagai persoalan, seperti korupsi, kolusi, nepotisme, kemiskinan, kekerasan, perusakan lingkungan, separatisme, dan hilangnya rasa kemanusiaan untuk menghormati hak-hak orang lain, merupakan bentuk nyata sebagai bagian dari multikulturisme tersebut.

Berbagai masalah yang timbul yang kompleksitasnya cenderung berujung konflik, banyak dikarenakan adanya keberagaman budaya yang memang pada dasarnya Indonesia adalah negara yang terdiri dari berbagai latar belakang sosial budaya meliputi ras, suku, agama, status sosial, mata pencaharian dan lain-lain sehingga bangsa Indonesia secara sederhana dapat disebut sebagai masyarakat "multikultur". Tetapi pada pihak lain, realitas "multikultur" tersebut berhadapan dengan kebutuhan mendesak untuk merekonstruksi kembali "kebudayaan nasional Indonesia" yang dapat menjadi integrating force yang mengikat seluruh keragaman etnis dan budaya tersebut.

Wajah multikultural di negeri ini hingga kini ibarat api dalam sekam, yang suatu saat bisa muncul akibat suhu politik, agama, sosial budaya yang memanas, yang memungkinkan konflik tersebut muncul kembali. Tentu penyebab konflik banyak sekali tetapi kebanyakan disebabkan oleh perbedaan politik, suku, agama, ras, etnis dan budaya. Beberapa kasus yang pernah terjadi di tanah air yang melibatkan kelompok masyarakat, mahasiswa bahkan pelajar karena perbedaan pandangan sosial politik atau perbedaan SARA tersebut.

Berbagai masalah yang timbul itulah yang akhirnya menjadi konflik berkepanjangan dan tidak bisa menemui titik terang atau jalan keluar untuk masalah yang menyangkut sosial budaya. Untuk itu diperlukan strategi khusus untuk memecahkan persoalan tersebut melalui berbagai bidang; sosial, ekonomi, budaya, dan pendidikan. Berkaitan dengan hal ini, maka pendidikan multikultural menawarkan satu alternatif melalui penerapan strategi dan konsep pendidikan yang berbasis pada pemanfaatan keragaman yang ada di masyarakat, khususnya yang ada pada siswa seperti keragaman etnis, budaya, bahasa, agama, status sosial, gender, kemampuan, umur, dan lain-lain. 
Dari paparan di atas agar dapat memberi dorongan dan spirit bagi lembaga pendidikan nasional terutama institusi-institusi pendidikan yang ada di dalamnya untuk mau menanamkan sikap kepada siswa untuk menghargai orang, budaya, agama, dan keyakinan lain. Harapannya, dengan implementasi pendidikan yang berwawasan multikultural, akan membantu siswa mengerti, menerima dan menghargai orang lain yang berbeda suku, budaya dan nilai kepribadian. Lewat penanaman semangat multikulturalisme di sekolah-sekolah atau institusi-institusi pendidikan akan menjadi medium pelatihan dan penyadaran bagi generasi muda (siswa) untuk menerima perbedaan budaya, agama, ras, etnis dan kebutuhan di antara sesama dan mau hidup bersama secara damai. Selain itu juga agar siswa memiliki kepekaan dalam menghadapi gejala-gejala dan masalah-masalah sosial yang berakar pada perbedaan karena suku, ras, agama dan tata nilai yang terjadi pada lingkungan masyarakatnya. Hal ini dapat diimplementasikan baik pada substansi maupun model pembelajaran yang mengakui dan menghormati keanekaragaman budaya.

\section{PEMBAHASAN}

\section{Pendidikan Multikultural}

Wacana tentang pendidikan merupakan salah satu wacana yang selalu mendapat perhatian besar terutama bagi pemerhati pendidikan. Pendidikan pada dasarnya harus selalu dikembangkan guna tercapainya hakikat yang sebenarnya dari sebuah pendidikan.

Merujuk pada penelitian yang dilakukan oleh Mansouri dan Trembath (2005) ${ }^{1}$ tentang "Multicultural Education and recism: The chase of Arab-Australia students in contemporary Australia”, mendeskripsikan pentingnya penerapan pendidikan multikultural. Pendidikan multikultural harus diterapkan disetiap sekolah. Hal ini disebabkan adanya berbagai etnis, ras dan budaya yang beragam yang dimiliki oleh setiap siswa. Hal ini dapat dijadikan sebagai dasar dalam mengimplementasikan pendidikan multikultural di Indonesia.

Sebagaimana diketahui, bahwa bangsa Indonesia mempunyai filsafat hidup Pancasila, dan Negara Kesatuan Republik Indonesia (NKRI) pun disusun atas dasar

${ }^{1}$ Mansouri, Fethi dan Anna Trembath. 2005. "“Multicultural Education and recism: The chase of Arab-Australia students in contemporary 
Pancasila. Untuk itu, sudah selayaknya jika pendidikan di Indonesia juga berdasarkan pada Pancasila, seperti termaktub dalam UU No. 4 tahun 1950, bab III pasal 4 tentang dasar-dasar pendidikan dan pengajaran yang berbunyi: pendidikan dan pengajaran berdasar atas asas-asas yang termaktub dalam pancasila undang-undang dasar (UUD) Negara Kesatuan Republik Indonesia dan atas kebudayaan kebangsaan Indonesia (Mudyahardjo, 2001: 45). ${ }^{2}$

Dasar dan tujuan pendidikan nasional yang sudah ditetapkan dalam UUD 1945 secara yuridis masih sama dengan dasar pendidikan nasional. Hal itu, ditetapkan kembali dalam Undang-Undang RI No. 20 pasal 1 ayat 2 tahun 2003, bahwa pendidikan nasional berdasarkan pada Pancasila dan Undang-Undang Dasar Negara Republik Indonesia tahun 1945 yang berakar pada nilai-nilai agama, kebudayaan nasional Indonesia, dan tanggapan terhadap tuntunan perubahan zaman (Mahfud, 2011: 44). ${ }^{3}$

Pendidikan merupakan salah satu media yang paling efektif untuk melahirkan generasi yang memiliki pandangan yang mampu menjadikan keragaman sebagai bagian yang harus diapresiasi secara konstruktif (Naim dan Sauqi, 2011: 8). ${ }^{4}$ Salah satu aspek yang perlu mendapat perhatian dalam dunia pendidikan adalah multikultural atau keragaman budaya. Pendidikan multikultural harus selalu ditanamkan pada setiap satuan pendidikan mulai dari pendidikan dasar sampai pendidikan tinggi.

Aly (2011: 105) menyatakan bahwa pendidikan multikultural didefinisikan sebagai pendidikan yang memperhatikan keragaman budaya para peserta didik. Definisi ini mendeskripsikan bahwa faktor penting yang harus diperhatikan dalam implementasi pendidikan multikultural adalah keragaman budaya siswa. karena siswa memiliki latar belakang budaya yang berbeda. ${ }^{5}$

Lebih lanjut, Banks dalam bukunya "Multicultural Education," mendefinisikan pendidikan multikultural sebagai berikut:

\footnotetext{
${ }^{2}$ Mudyahardjo, Redja. 2001. Filsafat Ilmu Pendidikan, Suatu Pengantar. Bandung: Remaja Rosdakarya.Hal 45

${ }^{3}$ Mahfud, Choirul. 2011. Pendidikan Multikultural. Yogyakarta: Pustaka Pelajar Hal 44

${ }^{4}$ Naim,Ngainun \& Achmad Sauqi. 2011. Pendidikan Multikultural Konsep dan Aplikasi. Jogjakarta: Hal 8

5 Aly, Abdullah. 2011. Pendidikan Islam Multikultural. Yogyakarta: Pustaka Pelajar Hal 105
} 
Multicultural education is an idea, an educational reform movement, and a process whose major goal is to change the structure of educational institutions so that male and female students, exceptional students, and students who are members of diverse racial, ethnic, and cultural groups will have an equal chance to achieve academically in school (2010:1)

Banks memberikan pemahaman bahwa pendidikan multikultural adalah ide, gerakan pembaharuan pendidikan dan proses pendidikan yang tujuan utamanya adalah untuk mengubah struktur lembaga pendidikan. Istilah pendidikan multikultural dapat digunakan baik pada tingkat deskriptif dan normatif yang menggambarkan isu-isu dan masalah-masalah pendidikan yang berkaitan dengan masyarakat multikultural (Mahfud, 2011: 180). ${ }^{6}$ Lebih lanjut Mahfud menjelaskan pendidikan multikultural mencakup pengertian tentang pertimbangan terhadap kebijakan-kebijakan dan strategi-strategi pendidikan dalam masyarakat multikultural.

Berdasarkan bebepapa definisi tentang pendidikan multikultural di atas, dapat disimpulkan bahwa pendidikan multikultural merupakan penanaman pendidikan tentang pemahaman keragaman budaya. Penanaman pendidikan multikultural harus diintegrasikan dalam kurikulum pembelajaran. Hal inilah yang akan menjadikan siswa memiliki pemahaman yang sungguh-sungguh dalam memahamai keragaman budaya yang ada disekitarnya.

Pendidikan multicultural tercermin dari sejumlah dimensi yang disimpulkan dari berbagai ahli, diantaranya:

\section{1) Conten integration}

Dimensi ini berkaitan dengan upaya untuk menghadirkan aspek kultur dari berbagai kultur yang ada ke ruang-ruang kelas. Seperti pakaian, tarian, kebiasaan, sastra, bahasa, dan sebagainya. Dengan demikian, diharapkan akan mampu mengembangkan kesadaran pada diri siswa akan kultur milik kelompok lain. Menurut Banks (Mahfud, 2011: 177), ${ }^{7}$ konsep-konsep atau nilai-nilai tersebut bisa diintegrasikan ke dalam materi-materi, metode pembelajaran, tugas/latihan, maupun evaluasi yang ada dalam buku pelajaran. Ditambahkannya pula bahwa materi-materi tersebut bisa berupa penyajian dan pengenalan berbagai budaya dan kelompok yang

${ }^{66}$ Mahfud, Choirul. 2011. Pendidikan Multikultural. Yogyakarta: Pustaka Pelajar.Hal 180

${ }^{7}$ Mahfud, Choirul. 2011. Pendidikan Multikultural. Yogyakarta: Pustaka Pelajar. Hal 177 
beragam. Dalam jurnal hasil penelitiannya, Novera (2004: 475) juga menyatakan bahwa isu-isu budaya dalam proses penyesuaian siswa sangat penting untuk diberikan, terutama dalam kaitannya dengan interaksi kelas antara guru dengan murid. ${ }^{8}$

Sedangkan dalam pengintegrasian materi yang berkaitan dengan bahasa yang beragam, Yaqin (2005: 104) menjelaskan bahwa siswa harus di didik untuk mempunyai sikap dan perilaku yang mampu menghargai orang lain yang mempunyai bahasa, aksen, dan dialek yang berbeda. Hal ini perlu dilakukan agar tidak terjadi adanya diskriminasi bahasa di sekolah.

\section{2) The knowledge construction process}

Pembelajaran memberikan kesempatan kepada siswa untuk memahami dan merekonstruksi berbagai kultur yang ada. Pendidikan multikultural merupakan pendidikan yang membantu siswa untuk mengembangkan kemampuan mengenal, menerima, menghargai, dan merayakan keragaman kultural.

Berdasarkan penelitian yang telah dilakukan, Kijima (2005: 133) menemukan tiga masalah dalam proses pembelajaran yang berlangsung di kelas/sekolah. Tiga masalah tersebut adalah keberagaman dan pemahaman bahasa, pemahaman budaya, dan adanya rasisme. Ketiga hal ini menjadi suatu masalah sehingga dapat menghambat proses interaksi dan pemahaman di antara siswa yang beragam latar belakang. Oleh sebab itu, dalam proses pemahaman pengetahuan tentang keberagaman bahasa, budaya, dan etnis/ras yang dilaksanakan dalam kegiatan pembelajaran, hendaknya jangan sampai terjadi hal-hal yang demikian. ${ }^{9}$

Jewell (2005: 494), dalam jurnal hasil penelitiannya, juga memberikan penegasan bahwa proses merekonstruksi pengetahuan yang dilaksanakan dalam proses pembelajaran harus mampu memberikan bekal kemampuan kepada siswa untuk bisa mengambil keputusan sendiri dalam menghadapi situasi kehidupan yang kompleks dan multikultural. ${ }^{10}$

\footnotetext{
${ }^{8}$ Novera, Ivet Amri. 2004. "Indonesian Postgradute Students Studying in Australia: An Examination of their Academic, Social and Cultural HL 475

${ }^{9}$ Education Journal. Vol. 6. no. 4. hal. 494-500.

Kijima, Miyako. 2005. "Schooling, multiculturalism and cultural identity: Hal 133

10 Jewell, Paul. 2005. "Autonomy and Liberalism in A Multicultural Society". Internatioanal Education Journal. Vol. 6. no. 4. hal. 494-500 Hal 494
} 


\section{3) Equity pedagogy}

Kesetaraan akan muncul apabila guru sudah mulai memodifikasi perilaku pembelajaran mereka disesuaikan dengan kondisi para siswa yang memiliki berbagai latar belakang yang berbeda, sehingga memberikan harapan bahwa semua siswa tanpa melihat latar belakang yang dimilikinya akan dapat mencapai hasil sebagaimana yang telah direncanakan. Pada tahap ini, para guru sudah mengembangkan pendekatan, model, strategi, metode, dan teknik pembelajaran yang mengarah pada student centered, pembelajaran di kelas yang bertumpu pada diri siswa sebagai seorang individu.

Dalam laporan jurnal hasil penelitian yang dilakukan, Winch (2004: 102) menyatakan bahwa proses dan praktik pembelajaran yang menargetkan pengakuan, nilai dan berbagai pandangan dunia dalam proses belajar mengajar perlu dilakukan sebagai upaya belajar bagi siswa untuk bisa hidup bersama dalam sebuah kelas multikultural. ${ }^{11}$ Dijelaskan pula bahwa pendidikan untuk masa depan harus diatur sebagaimana prinsip empat pilar dalam proses belajar, yaitu belajar untuk menjadi, belajar untuk melakukan, belajar untuk mengetahui, dan belajar untuk hidup bersama.

Dengan cara demikian, perbedaan antarindividu dapat dikembangkan sebagai suatu kekuatan kelompok, dan siswa terbiasa hidup dengan berbagai budaya, sosial, intelektualitas, ekonomi, dan aspirasi politik.

\section{4) Prejudice reduction}

Dimensi ini sebagai upaya agar para siswa menghargai adanya berbagai kultur dengan segala perbedaan yang menyertainya. Selain itu, siswa juga bisa memiliki sifat positif atas perbedaan tersebut. Hilda Hernandez (dalam Mahfud, 2011: 176) juga mengungkapkan bahwa sangat penting adanya refleksi budaya, ras, seksualitas dan gender, etnisitas, agama, status sosial, ekonomi dalam proses pendidikan multikultural. Hal ini sebagai bentuk pengakuan terhadap realitas politik, sosial, dan ekonomi yang dialami oleh masing-masing individu dalam proses pendidikan. ${ }^{12}$

\section{5) Empowering school culture and social structure}

Dimensi ini merupakan tahap dilakukannya rekonstruksi baik struktur sekolah maupun kultur sekolah. Hal ini diperlukan untuk memberikan jaminan kepada semua

11 Winch, Carlene and Dummett. 2004. "Teaching Processes and Practices for an Australian Multicultural Classroom: International Education Journal. Vol. 4. No. Hal. 102-113.

12 Mahfud, Choirul. 2011. Pendidikan Multikultural. Yogyakarta: Pustaka Pelajar. Hal 176 
siswa dengan latar belakang yang berbeda agar mereka merasa mendapatkan pengalaman dan perlakuan yang setara dalam proses pembelajaran di sekolah.

\section{Perspektif Pendidikan Multikultural Indonesia}

Di Indonesia walaupun masih seputar wacana, pendidikan multikultur relatif baru dikenal sebagai suatu pendekatan yang dianggap perlu bagi masyarakat Indonesia yang heterogen, terlebih pada masa otonomi dan desentralisasi yang baru dilakukan. Pendidikan multikultur yang dikembangkan di Indonesia sejalan pengembangan demokrasi yang dijalankan sebagai counter terhadap kebijakan desentralisasi dan otonomi daerah. Apabila hal itu dilaksanakan dengan tidak berhatihati justru akan menjerumuskan kita ke dalam perpecahan nasional.

Berakhirnya sentralisme kekuasaan yang pada masa orde baru memaksakan "monokulturalisme" yang nyaris seragam, memunculkan reaksi balik, yang bukan tidak mengandung implikasi-implikasi negatif bagi rekonstruksi kebudayaan Indonesia yang multikultur. Berbarengan dengan proses otonomisasi dan dan desentralisasi kekuasaan pemerintahan, terjadi peningkatan gejala "provinsialisme" yang hampir tumpang tindih dengan "etnisitas". Kecenderungan ini, jika tidak terkendali akan dapat menimbulkan tidak hanya disintegrasi sosio-kultural yang amat parah, tetapi juga disintegrasi politik.

Model pendidikan di Indonesia maupun di negara-negara lain menunjukkan keragaman tujuan yang menerapkan strategi dan sarana yang dipakai untuk mencapainya. Penambahan informasi tentang keragaman budaya merupakan model pendidikan multikultur yang mencakup revisi atau materi pembelajaran dan termasuk revisi buku-buku teks. Walaupun belum diterima, usaha ini sudah mulai membuka mata sebagian masyarakat akan pentingnya perspektif baru tentang perang, agar tragedi kemanusiaan tidak terulang kembali. Sedangkan di Indonesia masih diperlukan usaha yang panjang dalam merevisi buku-buku teks agar mengakomodasi kontribusi dan partisipasi yang lebih inklusif bagi warga dari berbagai latarbelakang dalam pembentukan Indonesia. Indonesia juga memerlukan pula materi pembelajaran yang bisa mengatasi konflik berkepanjangan di berbagai wilayah.

Model lainnya adalah pendidikan multikultur tidak sekadar merevisi materi pembelajaran tetapi melakukan reformasi dalam sistem pembelajaran itu sendiri 
seperti yang diungkapkan Muhaemin (2004). Affirmative action dalam seleksi siswa sampai rekrutmen pengajar di Amerika adalah salah satu strategi untuk membuat perbaikan ketimpangan struktural terhadap kelompok minoritas. Contoh yang lain adalah model "sekolah pembauran" Iskandar Muda di Medan yang memfasilitasi interaksi siswa dari berbagai latar belakang budaya dan menyusun program anak asuh lintas kelompok juga dilakukan berbagai lokakarya di sekolah-sekolah maupun di masyarakat luas untuk meningkatkan kepekaan sosial, toleransi dan mengurangi prasangka antar kelompok. ${ }^{13}$

Untuk mewujudkan model-model tersebut, pendidikan multikultur di Indonesia perlu memakai kombinasi model yang ada, agar seperti yang diajukan Gorski (Banks, 2010), pendidikan multikultur dapat mencakup tiga hal jenis transformasi, yakni: (1) transformasi diri; (2) transformasi sekolah dan proses belajar mengajar, dan (3) transformasi masyarakat. ${ }^{14}$

Menyusun pendidikan multikultur dalam tatanan masyarakat yang penuh permasalahan antara kelompok mengandung tantangan yang tidak ringan. Pendidikan multikultur tidak berarti sebatas "merayakan keragaman" belaka. Apalagi jika tatanan masyarakat yang ada masih penuh diskriminasi dan bersifat rasis. Dapat pula dipertanyakan apakah mungkin meminta siswa yang dalam kehidupan sehari-hari mengalami diskriminasi atau penindasan karena warna kulitnya atau perbedaannya dari budaya yang dominan tersebut? Dalam kondisi demikian pendidikan multikultur lebih tepat diarahkan sebagai advokasi untuk menciptakan masyarakat yang toleran dan bebas toleransi.

Implementasi pendidikan yang berwawasan multikultural, akan membantu siswa mengerti, menerima dan menghargai orang lain yang berbeda suku, budaya dan nilai kepribadian. Lewat penanaman semangat multikulturalisme di sekolah-sekolah, akan menjadi medium pelatihan dan penyadaran bagi generasi muda untuk menerima perbedaan budaya, agama, ras, etnis dan kebutuhan di antara sesama dan mau hidup bersama secara damai. Agar proses ini berjalan sesuai harapan, maka seyogyanya kita mau menerima jika pendidikan multikultural disosialisasikan dan didiseminasikan

${ }^{13}$ Muhaemin, E. (2004). "Multikulturralisme dan Pendidikan Multikultural

14 Banks, J.A. 2010. Multicultural Education: Issues and Perspectives. Needham Heights, Massachusetts :

Allyn and Bacon 
melalui lembaga pendidikan, serta, jika mungkin, ditetapkan sebagai bagian dari kurikulum pendidikan di berbagai jenjang baik di lembaga pendidikan pemerintah maupun swasta. Apalagi, paradigma multikultural secara implisit juga menjadi salah satu concern dari Pasal 4 UU N0. 20 Tahun 2003 Sistem Pendidikan Nasional. Dalam pasal itu dijelaskan, bahwa pendidikan diselenggarakan secara demokratis, tidak diskriminatif dengan menjunjung tinggi HAM, nilai keagamaan, nilai kultural dan kemajemukan bangsa.

\section{Kebijakan Yang Diperlukan}

Beberapa aspek yang menjadi kunci dalam melaksanakan pendidikan multikultur dalam struktur sekolah adalah tidak adanya kebijakan yang menghambat toleransi, termasuk tidak adanya penghinaan terhadap ras, etnis dan jenis kelamin. Juga, harus menumbuhkan kepekaan terhadap perbedaan budaya, di antaranya mencakup pakaian, musik, makanan kesukaan dan lain sebaginya yang secara struktur memiliki perbedaan. Selain itu, juga memberikan kebebasan bagi anak dalam merayakan hari-hari besar umat beragama serta memperkokoh sikap anak agar merasa butuh terlibat dalam pengambilan keputusan secara demokratis.

Fenomena dalam masyarakat yang merupakan kumpulan besar individu yang hidup dan bekerja sama dalam masa relatif lama, sehingga individu-individu dapat memenuhi kebutuhan mereka dan menyerap watak sosial. Kondisi itu selanjutnya membuat sebagian mereka menjadi komunitas terorganisir yang berpikir tentang dirinya dan membedakan ekstensinya dari ekstensi komunitas. Disisi lain, apabila kehidupan di dalam masyarakat berinteraksi antara individu dan lingkungan sosialnya, maka yang menjadikan pembentukan individu tersebut adalah pendidikan atau dengan istilah lain masyarakat pendidik.

Oleh karena itu, dalam melakukan kajian dasar kependidikan terhadap masyarakat, diperlukan dasar-dasar sebagai berikut :

1. Masyarakat tidak ada dengan sendirinya. Masyarakat adalah ekstensi yang hidup, dinamis, dan selalu berkembang.

2. Masyarakat bergantung pada upaya setiap individu untuk memenuhi kebutuhan melalui hubungan dengan individu lain yang berupaya memenuhi kebutuhan. 
3. Individu-individu, di dalam berinteraksi dan berupaya bersama guna memenuhi kebutuhan, melakukan penataan terhadap upaya tersebut dengan jalan apa yang disebut tantangan sosial.

4. Setiap masyarakat bertanggung jawab atas pembentukan pola tingkah laku antara individu dan komunitas yang membentuk masyarakat.

5. Pertumbuhan individu di dalam komunitas, keterikatan dengannya, dan perkembangannya di dalam bingkai yang menuntunnya untuk bertanggung jawab terhadap tingkah lakunya.

Bila penjelasan di atas ditarik di dalam dunia pendidikan, maka masyarakat sangat besar peranan dan pengaruhnya terhadap perkembangan intelektual dan kepribadian individu siswa. Sebab keberadaan masyarakat merupakan laboratorium dan sumber makro yang penuh alternatif untuk memperkaya pelaksanaan proses pendidikan.

Untuk itu, setiap anggota masyarakat memiliki peranan dan tanggung jawab moral terhadap terlaksananya proses pendidikan. Hal ini disebabkan adanya hubungan timbal balik antara masyarakat dan pendidikan. Dalam upaya memberdayakan masyarakat dalam dunia pendidikan merupakan satu hal penting untuk kemajuan pendidikan.

Memperhatikan uraian-uraian di atas, kebijakan-kebijakan yang perlu dilakukan dalam proses pendidikan multikultural, diantaranya:

Pertama, tidak lagi terbatas pada menyamakan pandangan pendidikan (education) dengan persekolahan (schooling) atau pendidikan multikultural dengan programprogram sekolah formal. Pandangan yang lebih luas mengenai pendidikan sebagai transmisi kebudayaan membebaskan pendidik dari asumsi bahwa tanggung jawab primer mengembangkan kompetensi kebudayaan di kalangan anak didik semata-mata berada di tangan mereka dan justru semakin banyak pihak yang bertanggung jawab karena program-program sekolah seharusnya terkait dengan pembelajaran informal di luar sekolah.

Kedua, menghindari pandangan yang menyamakan kebudayaan dengan kelompok etnik adalah sama. Artinya, tidak perlu lagi mengasosiasikan kebudayaan semata-mata dengan kelompok-kelompok etnik sebagaimana yang terjadi selama ini. secara tradisional, para pendidik mengasosiasikan kebudayaan hanya dengan 
kelompok-kelompok sosial yang relatif self sufficient, dibanding dengan sejumlah orang yang secara terus menerus dan berulang-ulang terlibat satu sama lain dalam satu atau lebih kegiatan. Dalam konteks pendidikan multikultural, pendekatan ini diharapkan dapat mengilhami para penyusun program-program pendidikan multikultural untuk melenyapkan kecenderungan memandang anak didik secara stereotip menurut identitas etnik mereka dan akan meningkatkan eksplorasi pemahaman yang lebih besar mengenai kesamaan dan perbedaan di kalangan anak didik dari berbagai kelompok etnik.

Ketiga, karena pengembangan kompetensi dalam suatu "kebudayaan baru" biasanya membutuhkan interaksi inisiatif dengan orang-orang yang sudah memiliki kompetensi, bahkan dapat dilihat lebih jelas bahwa uapaya-upaya untuk mendukung sekolah-sekolah yang terpisah secara etnik adalah antitesis terhadap tujuan pendidikan multikultural. Mempertahankan dan memperluas solidaritas kelompok adalah menghambat sosialisasi ke dalam kebudayaan baru. Pendidikan bagi pluralisme budaya dan pendidikan multikultural tidak dapat disamakan secara logis.

Keempat, pendidikan multikultural meningkatkan kompetensi dalam beberapa kebudayaan. Kebudayaan mana yang akan diadopsi ditentukan oleh sejarah dan situasi kondisi lingkungan sekitar.

Kelima, kemungkinan bahwa pendidikan (baik dalam maupun luar sekolah) meningkatkan kesadaran tentang kompetensi dalam beberapa kebudayaan. Kesadaran seperti ini kemudian akan menjauhkan kita dari konsep dwi budaya atau dikotomi antara pribumi dan non-pribumi. Dikotomi semacam ini bersifat membatasi individu untuk sepenuhnya mengekspresikan diversitas kebudayaan. Pendekatan ini meningkatkan kesadaran akan multikulturalisme sebagai pengalaman normal manusia. Kesadaran ini mengandung makna bahwa pendidikan multikultural berpotensi untuk menghindari dikotomi dan mengembangkan apresiasi yang lebih baik melalui kompetensi kebudayaan yang ada pada diri anak didik.

Dalam konteks keindonesiaan dan kebhinekaan, kelima kebijakan tersebut haruslah diselaraskan dengan kondisi masyarakat Indonesia. Masyarakat adalah kumpulan manusia atau individu-individu yang terjewantahkan dalam kelompok sosial dengan suatu tantangan budaya atau tradisi tertentu. Pendapat ini juga dikemukakan oleh Zakiah Darajat yang menyatakan, bahwa masyarakat secara 
sederhana diartikan sebagai kumpulan individu dan kelompok yang diikat oleh kesatuan negara, kebudayaan dan agama.

\section{Pendidikan Multikultural dalam Implementasi Kurikulum 2013}

Indonesia sebagai negara majemuk baik dalam segi agama, suku bangsa, golongan maupun budaya lokal perlu menyusun konsep pendidikan multikultural sehingga menjadi pegangan untuk memperkuat identitas nasional. Mata pelajaran Bahasa dan Sastra Indonesia yang telah diajarkan di Sekolah Dasar hingga perguruan tinggi, disempurnakan dengan memasukan pendidikan multikultural, seperti budaya lokal antar daerah kedalamnya, agar generasi muda bangga sebagai bangsa Indonesia yang selanjutnya dapat meningkatkan rasa nasionalisme. Dengan demikian, pendidikan multikultur adalah pendidikan nilai yang harus ditanamkan pada siswa sebagai calon warga negara, agar memiliki persepsi dan sikap multikulturalistik, bisa hidup berdampingan dalam keragaman watak kultur, agama dan bahasa, menghormati hak setiap warga negara tanpa membedakan etnik mayoritas atau minoritas, dan dapat bersama-sama membangun kekuatan bangsa sehingga diperhitungkan dalam percaturan global dan nation dignity yang kuat.

Menurut Hamid Hasan (2000), bahwa masyarakat dan bangsa Indonesia memiliki keragaman sosial, budaya, aspirasi politik dan kemampuan ekonomi. Keragaman tersebut berpengaruh langsung terhadap kemampuan guru dalam melaksanakan kurikulum, kemampuan sekolah dalam menyediakan pengalaman belajar dan kemampuan siswa dalam berproses, belajar dan mengolah informasi menjadi sesuatu yang dapat diterjemahkan sebagai hasil belajar. Keragaman itu menjadi suatu variabel bebas yang memiliki kontribusi sangat signifikan terhadap keberhasilan kurikulum, baik sebagai proses maupun sebagai hasil. ${ }^{15}$

Oleh karena itu, pengembangan kurikulum dengan menggunakan pendekatan pengembangan multikultural harus didasarkan pada empat prinsip. Pertama, keragaman budaya menjadi dasar dalam menentukan filsafat. Kedua,

\footnotetext{
${ }^{15}$ Hasan, Hamid S. (2000).”Multikulturalisme Untuk Penyempurnaan Kurikulum Nasional”. Jurnal
} Pendidikan dan Kebudayaan. 
keragaman budaya dijadikan dasar dalam mengembangkan berbagai komponen kurikulum, seperti tujuan, konten, proses, dan evaluasi. Ketiga, budaya di lingkungan unit pendidikan dari mulai pendidikan tingkat dasar sampai dengan perguruan tinggi sehingga sumber belajar dan objek studi harus dijadikan bagian dari kegiatan belajar siswa. Keempat, kurikulum berperan sebagai media dalam mengembangkan kebudayaan daerah dan nasional.

Implementasi pendidikan multikultur pada jenjang pendidikan dasar dan menengah, dapat dilakukan secara komprehensif melalui pendidikan Bahasa dan Sastra Indonesia, dapat dilakukan melalui pemberdayaan slot-slot kurikulum utamanya dalam buku teks siswa yang telah terintegrasi dengan contoh-contoh wacana dan gambar yang mencerminkan multikulturalistik.

Pendidikan multikultur melalui pendidikan Bahasa dan Sastra Indonesia harus dilakukan secara komprehensif, dimulai dari design perencanaan dan kurikulum melalui proses penyisipan, pengayaan dan atau penguatan terhadap berbagai kompetensi yang telah ada, mendesign proses pembelajaran yang bisa mengembangkan sikap siswa untuk bisa menghormati hak-hak orang lain, tapa membedakan latar belakang ras, agama, bahasa dan budaya. Pendidikan hasil dan pencapaian pendidikan multikultur harus dapat diukur melalui evaluasi yang relevan, apakah melalui instrumen tes, non-tes atau melalui proses pengamatan longitudinal dengan menggunakan portofolio siswa.

Sesuai dengan kompetensi standar tersebut, maka dapat dikembangkan beberapa kompetensi dasar sebagai berikut:

1. Menjadi warga negara yang menerima dan menghargai perbedaan-perbedaan etnik, agama, bahasa dan budaya dalam struktur masyarakatnya.

2. Menjadi waraga negara yang bisa melakukan kerjasama multi etnik, multi kultur, dan multi religi dalam konteks pengembangan ekonomi dan kekuatan bangsa.

3. Menjadi warga negara yang mampu menghormati hak-hak individu warga negara tanpa membedakan latar belakang etnik, agama, bahasa dan budaya dalam semua sektor sosial, pendidikan, ekonomi, politik dan lainnya, bahkan untuk memelihara bahasa dan mengembangkan budaya mereka.

4. Menjadi warga negara yang memberi peluang pada semua warga negara untuk 
terwakili gagasan dan aspirasinya dalam lembaga-lembaga pemerintahan, baik legislatif maupun eksekutif.

5. Menjadi warga negara yang mampu mengembangkan sikap adil dan mengembangkan rasa keadilan terhadap semua warga negara tanpa membedakan latar belakang etnik, agama, bahasa dan budaya mereka.

Dengan kompetensi-kompetensi dasar tersebut, maka pembelajaran multikultur diharapkan akan menghasilkan warga negara yang memiliki sikap dan kebiasaan multikultur dengan sikap dan prilaku yang toleran antar semua anak bangsa, solider dan bisa saling bekerjasama untuk kepentingan bangsa, bersikap egaliter, memiliki sikap empati sesama warga, dan bersikap adil dengan tidak membedakan latar belakang agama, ras, bahasa dan warna kulit.

Sejalan dengan konsepsi ini, John Dewey (1964) merekomendasikan tiga hal yang harus dipertimbangkan dalam mengembangkan sebuah kurikulum. "Pertama, hakikat dan kebutuhan peserta didik. Kedua, hakikat dan kebutuhan masyarakat. Dan ketiga, masalah pokok yang digumuli siswa untuk mengembangkan diri sebagai pribadi yang matang dan mampu menjalin hubungan dengan pribadi lain dalam masyarakat" ${ }^{16}$

Agar pendidikan multikultur ini dapat menghasilkan output atau lulusan yang tidak hanya kompeten sesuai dengan disiplin ilmu yang ada pada setiap institusi pendidikan ataupun yang ditekuninya, tetapi output tersebut juga mampu menerapkan nilai-nilai keberagaman dalam memahami dan menghargai keberadaan perbedaan yang ada maka penanaman nilai-nilai ini tidak hanya dilakukan pada mata pelajaran Kewarganegaraan dan Agama saja tapi dapat pula berintegrasi dengan mata pelajaran lain. Dimana penanaman nilai multikultur ini bisa dilakukan oleh seorang guru atau pendidik baik dalam pembelajaran di kelas atau dalam kegiatan sehari-hari. Contoh penanaman nilai multikultur antara lain tidak membeda-bedakan siswa, membentuk kelompok diskusi secara heterogen, pengambilan keputusan secara demokratis, memberi kebebasan bagi siswa dalam mengeluarkan pendapatnya atau bertanya, menghargai budaya dan bahasa dan lain-lain.

Dengan demikian pendidikan multikultur harus direncanakan dalam

${ }^{16}$ Dewey, John. 1964. Democracy and Education, New York: The Mac Millan Company. 
sebuah design pengembangan kurikulum yang integratif, sequentif dan didukung dengan lingkungan serta struktur dan budaya yang bisa memberikan kontribusi positif terhadap pembinaan sikap dan perilaku multikultur. Pendidikan multikultur, secara substantif harus bisa menjadi bagian integral baik dalam mata pelajaran pendidikan Bahasa dan Sastra Indonesia maupun mata pelajaran lain sebagai pendidikan nilai. Tema-tema multikultur harus disajikan dalam skope yang komprehensif sebagai upaya pencapaian berbagai kompetensi yang telah disepakati dan ditetapkan.

\section{Implementasi Pendidikan Multikultural Dalam Proses Pembelajaran}

Dari aspek metode strategi dan manajemen pembelajaran merupakan aspek penting dalam penerapan pendidikan multikultural. Harry K. Wong, penulis buku How to be an Active Teacher the First Days of School, sebagaimana dikutip Linda Starr (2004: 2) mendefinisikan manajemen pembelajaran sebagai "praktik dan prosedur yang memungkinkan guru mengajar dan siswa belajar." ${ }^{17}$ Terkait dengan praktik dan prosedur ini, Ricardo L. Garcia (1982: 146) menyebutkan 3 (tiga) faktor dalam manajemen pembelajaran, yaitu: (a) lingkungan fisik (physical environment), (b) lingkungan sosial (buman environment), dan (c) gaya pengajaran guru (teaching style). Dalam pembelajaran siswa memerlukan lingkungan fisik dan sosial yang aman dan nyaman. Untuk menciptakan lingkungan fisik yang aman dan nyaman, guru dapat mempertimbangkan aspek pencahayaan, warna, pengaturan meja dan kursi, tanaman, dan musik. ${ }^{18}$ Guru yang memiliki pemahaman terhadap latar belakang budaya siswanya, akan menciptakan lingkungan fisik yang kondusif untuk belajar. Sementara itu, lingkungan sosial yang aman dan nyaman dapat diciptakan oleh guru melalui bahasa yang dipilih, hubungan simpatik antar siswa, dan perlakuan adil terhadap siswa yang beragam budayanya. Dalam proses pembelajaran guru tidak membedakan gender, suku, ras, etnik dan lain-lain.

Selain lingkungan fisik dan sosial, siswa juga memerlukan gaya pengajaran guru yang menggembirakan. Menurut Garcia (1982: 146), gaya pengajaran guru merupakan

${ }^{17}$ Starr, Linda. 2004. "Creating a Climate for Learning: Effective Classroom Management Hal 2

${ }^{18}$ Garcia, Ricardo L. (1982). Teaching in a Pluristic Society: Concepts, Models, Strategies. New York: Harper \& Row Publisher.Hal 146 
gaya kepemimpinan atau teknik pengawalan yang digunakan guru dalam proses pembelajaran (the kind of leadership or governance techniques a teacher uses). Dalam proses pembelajaran, gaya kepemimpinan guru sangat berpengaruh bagi ada tidaknya peluang siswa untuk berbagi pendapat dan membuat keputusan. Gaya kepemimpinan guru berkisar pada otoriter, demokratis, dan bebas (laizzes faire). Gaya kepemimpinan otoriter tidak memberikan peluang kepada siswa untuk saling berbagi pendapat. Apa yang diajarkan guru kepada siswa ditentukan sendiri oleh sang guru. Sebaliknya, gaya kepemimpinan guru yang demokratis memberikan peluang kepada siswa untuk menentukan materi yang perlu dipelajari siswa. Selanjutnya, guru yang menggunakan gaya kepemimpinan bebas (laizzes faire) menyerahkan sepenuhnya kepada siswa untuk menentukan materi pembelajaran di kelas. Untuk kelas yang beragam latar belakang budaya siswanya, agaknya, lebih cocok dengan gaya kepemimpinan guru yang demokratis (Donna Styles, 2004: 3). ${ }^{19}$

Melalui pendekatan demokratis ini, para guru dapat menggunakan beragam strategi pembelajaran, seperti dialog, simulasi, bermain peran, observasi, dan penanganan kasus (Abdullah Aly, 2003). ${ }^{20}$ Melalui dialog para guru, misalnya, mendiskusikan sumbangan aneka budaya dan orang dari suku lain dalam hidup bersama sebagai bangsa. Selain itu, melalui dialog para guru juga dapat mendiskusikan bahwa semua orang dari budaya apa pun ternyata juga dapat saling berkolaborasi dalam berkreatifias dan berinovasi. Sementara itu, melalui simulasi dan bermain peran, para siswa difasilitasi untuk memerankan diri sebagai orang-orang yang memiliki agama, budaya, dan etnik tertentu dalam pergaulan sehari-hari. Dalam momen-momen tertentu, diadakan proyek dan kepanitiaan bersama, dengan melibatkan aneka macam siswa dari berbagai agama, etnik, budaya, dan bahasa yang beragam. Sedangkan melalui observasi dan penanganan kasus, siswa dan guru difasilitasi untuk tinggal beberapa hari di masyarakat multikultural. Mereka diminta untuk mengamati proses sosial yang terjadi di antara individu dan kelompok yang ada, sekaligus untuk melakukan mediasi bila ada konflik di antara mereka.

19 Styles, Donna. 2004. “Class Meetings: A Democratic Approach to Classroom Management”. Hal 3

20 Aly, Abdullah. 2011. Pendidikan Islam Multikultural. Yogyakarta: Pustaka Pelajar. 
Dengan strategi pembelajaran tersebut para siswa diasumsikan akan memiliki wawasan dan pemahaman yang mendalam tentang adanya keragaman dalam kehidupan sosial. Bahkan, mereka akan memiliki pengalaman nyata untuk melibatkan diri dalam mempraktikkan nilai-nilai dari pendidikan multikultural dalam kehidupan sehari-hari. Sikap dan perilaku yang toleran, simpatik, dan empatik pun pada gilirannya akan tumbuh pada diri masing-masing siswa. Dengan demikian, proses pembelajaran yang difasilitasi guru tidak sekadar berorientasi pada ranah kognitif, melainkan pada ranah afektif dan psikomotorik sekaligus.

Selanjutnya, pendekatan demokratis dalam proses pembelajaran dengan beragam strategi pembelajaran tersebut menempatkan guru dan siswa memiliki status yang setara (equal status), karena masing-masing dari mereka merupakan anggota komunitas kelas yang setara juga. Setiap anggota memiliki hak dan kewajiban yang absolut. Perilaku guru dan siswa harus diarahkan oleh kepentingan individu dan kelompok secara seimbang. Aturan-aturan dalam kelas harus dibagi untuk melindungi hak-hak guru dan siswa. Adapun hak-hak guru dalam proses pembelajaran meliputi: (a) guru berhak menilai para siswa sebagai manusia dan hak mereka sebagai manusia, (b) guru berhak mengetahui kapan menerapkan gaya pengajaran yang berbeda otoriter, demokratis, dan bebas untuk meningkatkan hak-hak siswa, (c) guru berhak mengetahui kapan dan bagaimana menerapkan ketidakpatuhan sipil, dan (d) guru berhak memahami kompleksitas aturan bagi mayoritas dan melindungi hak-hak minoritas. Di pihak lain, para siswa memiliki hak-hak sebagai berikut: (a) siswa berhak mengetahui hak sipil dan kewajibannya, dan (b) siswa berhak mengetahui bagaimana menggunakan hak dan kewajibannya (Garcia, 1982: 160). ${ }^{21}$

Lebih jauh, pendekatan demokratis dalam pembelajaran ini menuntut guru memiliki kompetensi multikultural. Farid Elashmawi dan Philip P. Harris (1994: 6-7) menawarkan 6 (enam) kompetensi multikultural guru, yaitu: (a) memiliki nilai dan hubungan sosial yang luas, (b) terbuka dan fleksibel dalam mengelola keragaman siswa, (c) siap menerima perbedaan disiplin ilmu, latar belakang, ras, dan gender; (d) memfasilitasi pendatang baru dan siswa yang minoritas, (e) mau berkolaborasi dan koalisi dengan pihak mana pun, dan (f) berorientasi pada program dan masa depan.

${ }^{21}$ Garcia, Ricardo L. (1982). Teaching in a Pluristic Society: Concepts, Models, Strategies. New York: Harper \& Row Publisher 
Selain itu, James A. Bank (2010) menambahkan kompetensi multikultural lain yang harus dimiliki oleh guru, yaitu: (a) sensitif terhadap perilaku etnik para siswa, (b) sensitif terhadap kemungkinan adanya kontroversi tentang materi ajar, dan (c) menggunakan teknik pembelajaran kelompok untuk mempromosikan integrasi etnik dalam pembelajaran. ${ }^{22}$

Implementasi pendidikan multikultur pada institusi pendidikan diperlukan pula penanaman nilai-nilai budaya dan karakter bangsa, dimana penanaman nilai-nilai tersebut hendaknya tercantum di dalam kurikulum 2013 dan juga dilakukan di dalam proses pembelajaran di kelas pada setiap mata pelajaran.

Adapun nilai-nilai budaya dan karakter tersebut diantaranya adalah Religius, Jujur, Toleransi, Disiplin, Kerja keras, Kerja Sama, Kreatif, Mandiri, Demokratis, Rasa ingin tahu, Semangat kebangsaan, Cinta tanah air, Menghargai prestasi, Bersahabat/Komunikatif, Cinta damai, Percaya Diri, Gemar membaca, Peduli lingkungan, Peduli sosial, Tanggungjawab.

Contoh penanaman nilai-nilai budaya dan karakter bangsa pada proses pembelajaran antara lain diskusi kelompok di dalam kelas atau ruang kuliah untuk menyelesaikan suatu materi atau soal yang diberikan oleh guru atau dosen (penanaman nilai Kerja Sama, Bersahabat dan Komunikatif), pembiasaan berdoa di setiap awal pembelajaran di kelas atau ruang kuliah (nilai Religius), pembiasaan saling salaman antar teman di pagi hari dan ketika pulang sekolah (nilai Persahabatan dan Cinta Damai), melaksanakan upacara bendera atau menyanyikan lagu wajib nasional untuk selingan (menumbuhkan Semangat Kebangsaan dan Cinta Tanah Air), melakukan kegiatan bakti sosial pada kegiatan-kegiatan kesiswaan (menumbuhkan nilai Peduli Sosial) dan lain-lain.

Dengan demikian pendidikan multikultural yang di dalamnya terdapat nilai-nilai budaya dan karakter bangsa memiliki urgensi yang sangat tinggi untuk diimplementasikan ke dalam dunia pendidikan baik itu di dalam kurikulumnya, kegiatan-kegiatan siswa/mahasiswa dan proses pembelajaran ataupun perkuliahan.

22Banks, J.A. 2010. Multicultural Education: Issues and Perspectives. Needham Heights, Massachusetts : Allyn and Bacon. 


\section{KESIMPULAN}

Pendidikan multikultur sebagai wacana baru di Indonesia namun urgensi implementasinya sudah sangat tinggi mengingat fenomena dan fakta yang sudah sangat kompleks sehingga implementasinya tidak hanya melalui pendidikan formal namun juga pendidikan non formal akademik dan non akademik yang dapat dimplementasikan dalam kehidupan masyarakat maupun dalam keluarga. Dalam pendidikan formal pendidikan multikultur ini dapat diintegrasikan dalam sistem pendidikan melalui kurikulum mulai Pendidikan Anak Usia Dini, TK, SD, SMP, SMA maupun Perguruan Tinggi. Implementasi pendidikan multikultural ini dapat melalui kurikulum tiap jenjang pendidikan, program-program kesiswaan maupun di dalam pembiasaan-pembiasaan dalam proses pembelajaran sehari-hari baik di lingkungan sekolah maupun keluarga. Pensisipan pendidikan multikultur ini dapat dilakukan dalam penanaman nilai-nilai multikultur tersebut ke dalam Kurikulum 2013 ataupun kegiatan pembelajaran yang responsive multikultur dengan mengedepankan penghormatan terhadap perbedaan baik ras suku, maupun agama antar anggota masyarakat.

Tak kalah penting wacana pendidikan multikultur ini dapat diimplementasikan dalam lingkup keluarga. Di mana keluarga sebagai institusi sosial terkecil dalam masyarakat, merupakan media pembelajaran yang paling efektif dalam proses internalisasi dan transformasi nilai, serta sosialisasi terhadap anggota keluarga. Peran orangtua dalam menanamkan nilai-nilai yang lebih responsive multikultur dengan mengedepankan penghormatan dan pengakuan terhadap perbedaan yang ada di sekitar lingkungannya (agama, ras, golongan) terhadap anak atau anggota keluarga yang lain merupakan cara yang paling efektif dan elegan untuk mendukung terciptanya sistem harmoni sosial yang lebih berkeadilan. 


\section{DAFTAR PUSTAKA}

Aly, Abdullah. 2011. Pendidikan Islam Multikultural. Yogyakarta: Pustaka Pelajar.

Banks, J.A. 2010. Multicultural Education: Issues and Perspectives. Needham Heights, Massachusetts : Allyn and Bacon.

Dewey, John. 1964. Democracy and Education, New York: The Mac Millan Company.

Garcia, Ricardo L. (1982). Teaching in a Pluristic Society: Concepts, Models, Strategies. New York: Harper \& Row Publisher.

Hasan, Hamid S. (2000).'Multikulturalisme Untuk Penyempurnaan Kurikulum Nasional". Jurnal Pendidikan dan Kebudayaan.

Jewell, Paul. 2005. "Autonomy and Liberalism in A Multicultural Society". Internatioanal Education Journal. Vol. 6. no. 4. hal. 494-500.

Kijima, Miyako. 2005. "Schooling, multiculturalism and cultural identity: Case study of Japanese senior school students in a secondary school in South Australia". International Education Journal. Vol. 5. no. 5. hal. 129-136.

Naim, Ngainun \& Achmad Sauqi. 2011. Pendidikan Multikultural Konsep dan Aplikasi. Jogjakarta: Ar-ruzz Media.

Mansouri, Fethi dan Anna Trembath. 2005. "“Multicultural Education and recism: The chase of Arab-Australia students in contemporary Australia". International Education Journal. Vol. 6. no. 4. Hal. 516-529.

Mahfud, Choirul. 2011. Pendidikan Multikultural. Yogyakarta: Pustaka Pelajar.

Mudyahardjo, Redja. 2001. Filsafat Ilmu Pendidikan, Suatu Pengantar. Bandung: Remaja Rosdakarya.

Muhaemin, E. (2004). "Multikulturralisme dan Pendidikan Multikultural".http://researchengines.com/muhaemin6-04.html. Diunduh 30 Oktober 2014

Novera, Ivet Amri. 2004. "Indonesian Postgradute Students Studying in Australia: An Examination of their Academic, Social and Cultural Experiences". Internatioanl Education Journal. Vol. 5. no. 4. hal. 475-487.

Starr, Linda. 2004. "Creating a Climate for Learning: Effective Classroom Management

Technique".http://www.educationworld.com/a_curr/curr155.shtml.Diund uh 30 Oktober 2014

Styles, Donna. 2004. "Class Meetings: A Democratic Approach to Classroom Management".

http://www.educationworld.com/a_curr/profdev012.shtml". Diunduh 1 November 2014

Tilaar, H.A.R. 2002. Perubahan Sosial dan Pendidikan: Pengantar Pedagogik Transformasi untuk Indonesia. Jakarta: Grasindo.

Winch, Carlene and Dummett. 2004. "Teaching Processes and Practices for an Australian Multicultural Classroom: Two Complementary Models. International Education Journal. Vol. 4. No. 4. Hal. 102-113.

Yaqin, Ainul. 2005. Pendidikan Multikultural; Cross-Cultur Understanding untuk Demokrasi dan Keadilan. Yogyakarta: Pilar Media. 